\title{
EFFECT OF THE SNAIL PARASITIC NEMATODE Phasmarhabditis tawfiki AZZAM ON SOME SNAILS AND INSECTS IN DIFFERENT TYPES OF SOILS UNDER THE GREEN HOUSE CONDITIONS
}

\author{
( Received: 23.8. 2007 )
}

By

\section{K. M. Azzam, M. M. Khattab and E. Ae. Khalifa *}

Plant Protection Research Institute, Agricultural Research Center, Dokki, Giza, Egypt.

*Department of Economic Entomology and Pesticides, Faculty of Agriculture, Cairo University, Giza, Egypt.

\begin{abstract}
The capability of Phasmarhabditis tawfiki Azzam to control the snails Eobania vermiculata (Müller) and Theba pisana (Müller) and the insect larvae of Agrotis ipsilon (Hüfngel) and Spodoptera littoralis (Boisd.) was investigated under greenhouse conditions, using three types of soils (clay, mixture of sand and clay, and sand), using an infective dose of about 200 I.S per snail or larva for four weeks .

The mortality rate of Eobania vermiculata (Müller), Theba pisana (Müller), Agrotis ipsilon (Hüf.) and Spodoptera littoralis (Boisd.) exposed to infection with P. tawfiki was 88.94, 83.75, 93.75 and 71.25 $\%$, respectively in the clay soil. In the mixture of sand and clay soil, these rates were $67.5,72.5,70$ and $60 \%$, while in the sand soil they recorded, $53.75,63.75,62.5$ and $52.5 \%$, respectively.

The highest number of recovered nematodes (14579.09 I.S./snail) was reported for the snail $E$. vermiculata infected in the clay soil. Reversely, the lowest number(2560 I.S./larva) was associated with larvae S. littoralis in the sandy soil. T. pisana and A. ipsilon recorded 9807.17 I.S./snail and 6803.28 I.S./ larva respectively in the clay soil.

Rates of individuals recovered nematodes in the clay soil were $89.94,85.04,82.79$ and $79.01 \%$ for E. vermiculata, T. pisana, A. ipsilon and S. littoralis, respectively.
\end{abstract}

Key words : Agrotis ipsilon, Eobania vermiculata, insects, Phasmarhabditis tawfiki Azzam, snails, Spodoptera littoralis, Theba pisana .

\section{1- INTRODUCTION}

Terrestrial snails are very prevalent animals in Egypt causing damage to all plant parts, from root to fruit of more than 47 species from ornamental plants, orchard crops, vegetables, field crops and medicinal plants including very economically important plants such as wheat, citrus, and potato (Azzam, 1995).The greasy cutworm, Agrotis ipsilon attacks about 50 plant species including wheat, cotton and potato (Amin and Abdin, 1997 and El Malki et al., 1998). Spodoptera littoralis attacks several plants including cotton (Khattab, 1988). Wilson et al. (1994) investigated the effect of Phasmarhabditis hermaphrodita (Schneider) on slug populations and their damage to winter wheat under field conditions. They found that seedling survival increased and slug damage to seedlings declined linearly with increasing log nematode dose. Wilson et al. (1996) studied the effect of soil incorporation of nematodes on the efficacy of $P h$. hermaphrodita and found that nematode application reduced slug damage to plants in plots where nematodes were incorporated into the soil but not when they were left on the surface as a drench.

Ph. tawfiki Azzam was first recorded and described by Azzam (2003). The capability of this nematodes to infect and kill some terrestrial snails and slugs, aquatic snails and some insect larvae was investigated by Azzam and Tawfik (2003). The biology of this nematodes was also studied by Azzam (2004a). She found that the infective dauer larvae (third stage inside the retained second stage cuticle) move through the thin film of water in the soil searching for their hosts. Once they have found their hosts, the nematodes invade them through their natural openings and develop inside the host into hermaphroditic females and sometimes reproduce very few males. The same authoress (2004b) studied the 
effect of soil type on the capability of Ph. tawfiki Azzam to infect snails under laboratory and semifield conditions and she mentioned that this parasitic nematodes, recorded a higher mortality of snails in clay than in sand or a mixture of both. The present contribution aimed to investigate the potential of Ph. tawfiki to control some harmful snails and insects under the greenhouse conditions and to check the possible role of this nematode as a biocontrol agent of these harmful pests in the field.

\section{MATERIALS AND METHODS}

The snail parasitic nematode $P h$. tawfiki Azzam was obtained from the progeny of the original colony which was isolated from Eobania vermiculata Müller and $L$. flavus Linneaus by Azzam (2003) using the same technique previously described by Azzam (1998). E.obania vermiculata Müller was reared by the technique previously described by Azzam (1995). A. ipsilon (Hüf.) and S. littoralis (Boisd.) were reared by the method described by Khattab (2003).

Three types of soils were tested i.e., clay, sand and a mixture of them (1:1). The soil was first sterilized at $160-180{ }^{\circ} \mathrm{C}$ for $2-4$ hours. The sterilized soil was placed into plastic pots $(20 \mathrm{~cm}$ inner diameter), sterilized by $10 \% \mathrm{HCl}$ acid or $90 \%$ ethanol alcohol, then well washed by distilled water. Four pots were used for each type of soil for each pest. Each pot was filled with soil to $5 \mathrm{~cm}$ height. One nursery of lettuce plant Lactuca sativa was planted in the middle of each pot as a food source for the snails or insect larvae.

The pots were irrigated without submersion (inundation). Twenty laboratory bred individuals of E.vermiculata, Theba pisana, recent fifth larval stage of A. ipsilon or S. littoralis were placed in each pot.. About 4000 I.J. from the parasitic nematode $P$. tawfiki were added to each pot in the treatment.

Dead individuals from each pest species were removed during the daily examination, and treated similarly to the technique described by Azzam (1998, 2004b).

Counting the nematodes was carried out according to Azzam, (1999 and 2004b) by taking $5 \mu \mathrm{l}$ of the nematode suspension using a micropipette after shaking thoroughly. The sample was placed on a micrometer slide and examined under the light microscope. This procedure was repeated four times. The mean number of nematodes was recorded and a volume adjusted to contain 4000 I.S, then added to each pot. Also the same technique was used for counting the nematodes recovered from dead snails and larvae but the mean number was adjusted as a function of the volume of the recovered nematode suspension. Such checking was made daily until the complete disappearance of emerging nematodes. Experimental pots were covered by Perlon gauze cloth and secured with a rubber band. The pots were checked daily and dead individuals were treated similarly to those of the laboratory experiment. Soil in the pots was sprayed with dechlorinated water if necessary to avoid dryness of the nematodes.

The mortality \% of each pest species, the period from infection to death and from death to nematode recovery, the ratios of individuals recovered nematodes and the number of recovered nematodes were recorded during daily examination. Results were statistically analyzed by ANOVA two ways and Duncan's multiple range test.

\section{RESULTS AND DISCUSSION}

Rates of mortality of the four pest species individuals infected with the snail parasitic nematode Ph. tawfiki Azzam, the period from infection to death and from death to nematode recovery, recovered nematodes as individual, and number of recovered nematodes are recorded in Table (1). The table shows that Ph. tawfiki caused mortality of $E$.vermiculata reached 88.94 $\%$ in the clay soil, $67.5 \%$ in the mixture soil and $53.75 \%$ in the sand soil. These ratios reached $83.75,72.5,63.75 \%, T$. pisana in the three types of soil, respectively. These ratios were 93.75 and 70, $62.5 \%$ in A. ipsilon, and 71.25,60 and $52.5 \%$ in S. littoralis. Statistical analysis showed very highly significant differences between the three types of soils and significant differences between S. littoralis and all other pest species in the clay and mixture soils, while significant differences existed between snails and insects larvae in the sand soil.

Recovery of infective stages of the parasitic nematode $P h$. tawfiki reached 5.94, 78.79 and $82.85 \%$ from dead infected $E$. vermiculata in the clay, mixed clay and sand and sand soil, respectively. These ratios were $85.04,80.43$ and $72.29 \%$ from $T$. pisana $82.79,82.06$ and $71.29 \%$ from A. ipsilon and 79.01,71.09 and $71.36 \%$ from $S$. littoralis, respectively.

Statistical analysis showed significant differences between the clay and sand soil, snails and insect larvae in the clay and mixed soils, between $E$.vermiculata and other pest species in the sand soil. Very highly significant differences 
Table (1): Effect of Phasmarhabditis tawfiki Azzam on different pest species in different types of soil under green house conditions

\begin{tabular}{|c|c|c|c|c|c|c|}
\hline \multirow[t]{2}{*}{ Type of soil } & \multirow[t]{2}{*}{ Pest species } & \multirow[t]{2}{*}{ Mortality\% } & \multicolumn{2}{|c|}{ The period (in days)from } & \multirow{2}{*}{$\begin{array}{c}\% \text { of individuals } \\
\text { recovered nematodes }\end{array}$} & \multirow{2}{*}{$\begin{array}{c}\text { Number of recovered } \\
\text { nematodes }\end{array}$} \\
\hline & & & $\begin{array}{c}\text { Infection to death } \\
\text { Mean } \pm \text { S.D (Range) }\end{array}$ & Death to recovery & & \\
\hline \multirow[t]{4}{*}{ Clay } & Eobania vermiculata & $88.94 \mathrm{Aa}$ & $\begin{array}{c}6.87 \pm 2.65 \text { Aa } \\
(3-12)\end{array}$ & $\begin{array}{c}4.80 \pm 1.38 \\
(3-8)\end{array}$ & 85.94Aa & $\begin{array}{c}14679.09 \pm 2290.65 \mathrm{Aa} \\
(11400-18600)\end{array}$ \\
\hline & Theba pisana & $83.75 \mathrm{Aa}$ & $\begin{array}{c}11.72 \pm 5.77 \mathrm{Ab} \\
(4-23)\end{array}$ & $\begin{array}{c}4.88 \pm 1.42 \\
(3-8)\end{array}$ & $85.04 \mathrm{Aa}$ & $\begin{array}{c}9807.17 \pm 2700.45 \mathrm{Ab} \\
(6950-13200)\end{array}$ \\
\hline & Agrotis ipsilon & $93.75 \mathrm{Aa}$ & $\begin{array}{c}6.72 \pm 3.1 \mathrm{Aa} \\
(1-12)\end{array}$ & $\begin{array}{c}4.73 \pm 1.12 \\
(3-7)\end{array}$ & 82.79Aab & $\begin{array}{c}6803.28 \pm 1290.35 \mathrm{Ac} \\
(4900-8300)\end{array}$ \\
\hline & Spodoptera littoralis & $71.25 \mathrm{Ab}$ & $\begin{array}{l}4.77 \pm 2.34 \text { Ac } \\
(2-11)\end{array}$ & $\begin{array}{c}4.86 \pm 1.17 \\
(3-8)\end{array}$ & $79.01 \mathrm{Ab}$ & $\begin{array}{c}3267.05 \pm 514.17 \mathrm{Ad} \\
(2300-4200)\end{array}$ \\
\hline \multirow[t]{4}{*}{$\begin{array}{l}\text { Mixture of } \\
\text { clay and sand }\end{array}$} & Eobania vermiculata & $67.5 \mathrm{Ba}$ & $\begin{array}{l}7.55 \pm 2.5 \mathrm{Aa} \\
(3-13)\end{array}$ & $\begin{array}{l}5.03 \pm 1.35 \\
(3-8)\end{array}$ & 78.79ABa & $\begin{array}{c}12487.03 \pm 2102.08 \mathrm{Ba} \\
(9200-16200)\end{array}$ \\
\hline & Theba pisana & $72.5 \mathrm{Ba}$ & $\begin{array}{l}12.29 \pm 5.70 \mathrm{Ab} \\
(4-22)\end{array}$ & $\begin{array}{c}5.16 \pm 1.36 \\
(3-8)\end{array}$ & $80.43 \mathrm{ABa}$ & $\begin{array}{c}9166 \pm 1733.18 \mathrm{~B} \mathrm{~b} \\
(6200-12200)\end{array}$ \\
\hline & Agrotis ipsilon & $70 \quad \mathrm{Ba}$ & $\begin{array}{c}8.89 \pm 3.88 \mathrm{Aa} \\
(1-16)\end{array}$ & $\begin{array}{c}4.53 \pm 1.07 \\
(3-7)\end{array}$ & $82.06 \mathrm{ABb}$ & $\begin{array}{c}5280.70 \pm 1294.28 \mathrm{Bc} \\
(3500-7800)\end{array}$ \\
\hline & Spodoptera littoralis & $60 \mathrm{Bb}$ & $\begin{array}{c}5.39 \pm 2.63 \mathrm{Ac} \\
(2-11)\end{array}$ & $\begin{array}{c}4.85 \pm 1.15 \\
(3-7)\end{array}$ & $71.09 \mathrm{ABc}$ & $\begin{array}{c}2764.71 \pm 376.49 \mathrm{Bd} \\
(2000-3400)\end{array}$ \\
\hline \multirow[t]{4}{*}{ Sand } & Eobania vermiculata & $53.75 \mathrm{Ca}$ & $\begin{array}{c}6.91 \pm 2.55 \mathrm{Aa} \\
(4-12)\end{array}$ & $\begin{array}{l}5 \pm 1.143 \\
(4-7)\end{array}$ & $82.85 \mathrm{Ba}$ & $\begin{array}{c}10993.23 \pm 2209.58 \mathrm{Ca} \\
(8100-14600)\end{array}$ \\
\hline & Theba pisana & $63.75 \mathrm{Cb}$ & $\begin{array}{c}9.82 \pm 4.83 \mathrm{Ab} \\
(3-20)\end{array}$ & $\begin{array}{c}5.07 \pm 1.26 \\
(3-8)\end{array}$ & $72.29 \mathrm{Bb}$ & $\begin{array}{l}8442.73 \pm 2338.65 \mathrm{Cb} \\
\quad(5400-12200)\end{array}$ \\
\hline & Agrotis ipsilon & $62.5 \mathrm{Cb}$ & $\begin{array}{c}8.18 \pm 3.66 \mathrm{Ab} \\
(2-16)\end{array}$ & $\begin{array}{c}4.86 \pm 1.18 \\
(3-7)\end{array}$ & $71.29 \mathrm{Bb}$ & $\begin{array}{l}3954.51 \pm 696.40 \mathrm{Cc} \\
(3000-6000)\end{array}$ \\
\hline & Spodoptera littoralis & $52.5 \mathrm{Ca}$ & $\begin{array}{l}5.41 \pm 2.45 \mathrm{Ac} \\
\quad(2-10)\end{array}$ & $\begin{array}{l}4.73 \pm 1.14 \\
(3-7)\end{array}$ & $71.36 \mathrm{Bb}$ & $\begin{array}{c}2560 \pm 403.95 \mathrm{Cd} \\
(2000-3200)\end{array}$ \\
\hline \multirow[t]{3}{*}{ F value } & For soils & 97.3 & 2.047 & 0.97 & 6.49 & 101.97 \\
\hline & For pests & 19.5 & 137.89 & 1.18 & 4.88 & 141.199 \\
\hline & Interaction between them & 4.01 & 0.74 & 0.85 & 1.68 & 112.86 \\
\hline \multirow[t]{3}{*}{$\mathrm{P}$} & For soils & $.0000 * * *$ & 14 n.s. & $.38 \mathrm{n} . \mathrm{s}$. & $.004 * *$ & $.0000 * * *$ \\
\hline & For pests & $.0000 * * *$ & $.0000 * * *$ & .33 n. s. & $.005 * *$ & $.0000 * * *$ \\
\hline & Interaction between them & $.003 * *$ & .62 n. s. & .53 n. s. & $.38 \mathrm{n} . \mathrm{s}$. & $.0000 * * *$ \\
\hline
\end{tabular}

Number between brackets: (Range ), Number $\pm=$ Mean \pm SD, $* *=$ Highly significant $. * *=$ Very highly significant, $\mathrm{n}$. $\mathrm{s}$. =not significant ,

Numbers with different letter either small or capital have highly significant differences between them. 


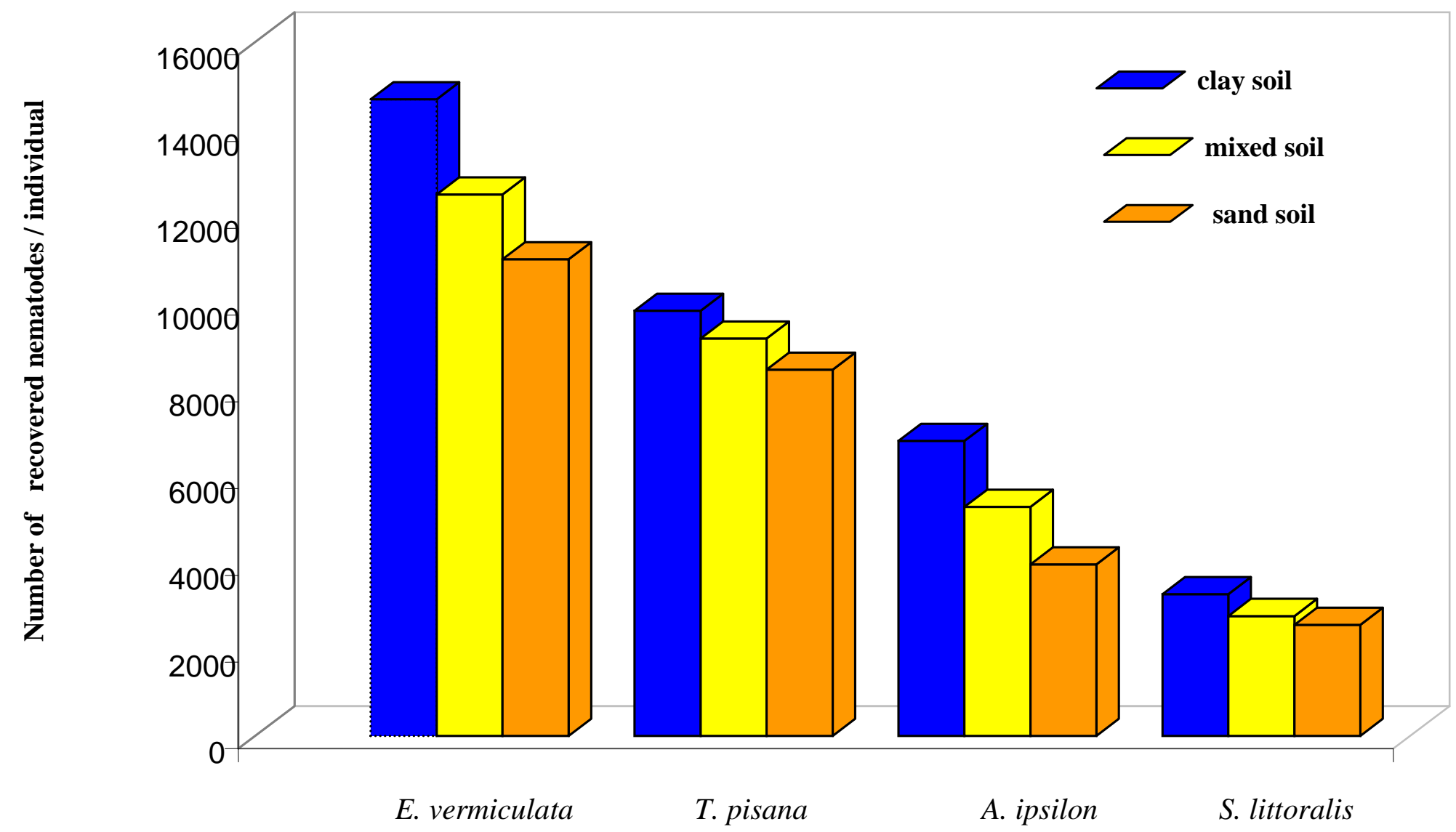

Different pest species and soils

Fig.(1): Number of nematodes recovered from different pest species in three types of soil. 
existed between $S$. littoralis and snails. The highest number of recovered nematodes $(14679.09 \pm 2290.65)$ was reported for the snail E. vermiculata infected in the clay soil followed by T. pisana and A. ipsilon( Fig.1). Reversely, the lowest number $(2560 \pm 403.95)$ was associated with $S$. littoralis in the sandy soil. $E$. vermiculata had the highest number in all types of soils. This may be attributed to its larger size and because it is the natural host of the nematode Ph. tawfiki Azzam .

Statistical analysis showed very high significant differences between the three types of soils and between E. vermiculata and all other pest species in all types of soils. Highly significant differences existed between $T$. pisana and both species of insect larvae and significant differences between $S$. littoralis and A. ipsilon in all soil types. Concerning the period from infection to death, no significant differences existed between the types of soils but very high significant differences existed between different pest species (Table,1). No significant differences existed between different pest species or soils in the period from death to recovered nematodes (Table, 1).

The aforementioned results indicate more suitability of the clay soil to the ability of $P h$. tawfiki to infect. Vermiculata, T. pisana, A. ipsilon and $S$. littoralis than the sand or mixted soil . Azzam (2004a\&b) reported more suitability of the clay soil to persistence and activity of $P h$. tawfiki than the sand and mixed soil when infected E. vermiculata. Reversely, Molyneux and Bedding (1984) mentioned that Steinernema. glaseri showed more infectivity in sand than in mud, while Heterorhabditis sp. became more effective in the last (mud) soil.

The present investigation showed clearly that the snail parasitic nematodes, $P$. tawfiki, produced high enough mortality rates to play an important role in controlling the abovementioned pest species especially those infesting plants in clay soil.

\section{4- REFERENCES}

Amin A.A.H and Abdin M.I. (1997). Preliminary analysis of field population of black cutworm, Agrotis ipsilon (Hüfn.) and some measurements for its field life table in Egypt. Proceedings Beltwide Cotton Conferences, New Orleans, LA, USA, January 6-10, Vol 2: 1116-1118.
Azzam K. M. (1995). Studies on Some Malacophagous Insects in Egypt. Ph. D. Thesis, Fac. Agric., Cairo Univ., 326 PP.

Azzam, K. M. (1998). First record of snail parasitic nematode Rhabditis sp. isolated from Egyptian terrestrial snails and its capability to infect other pests. Egyptian Journal of Biological Pest Control 8(1): 2729.

Azzam K. M. (1999). Production of the snail parasitic nematode Rhabditis $\mathrm{sp}$. from different pests. Proceedings of the First Regional Symposium for Applied Biological Control in Mediterranean Countries, Cairo, Egypt. October 25-29,1998 p.45-49.

Azzam, K. M. (2003). Description of Phasmarhabditis tawfiki n. sp. isolated from Egyptian terrestrial snails and slugs. Egyptian German Socicty Journal of Zoology (42D): 79-87.

Azzam, K. M. (2004a). Biological studies on the snail parasitic nematode Phasmarhbditis tawfiki Azzam (Nematoda: Rhabditidae). Egyptian German Society Journal of Zoology (45E): 153-162.

Azzam K. M. (2004b). Effect of soil type on the capability of Phasmarhabditis tawfiki Azzam to infect snails under laboratory and outdoor conditions. Egyptian J. Biol. P. Cont., 14(2): 387-390.

Azzam K. M. and Tawfik M.F.S.(2003): Capability of the nematode Phasmarhabditis tawfiki Azzam to infect some snails, slugs and insect larvae in the laboratory. Egyptian German Society Journal of Zoology (42D): 27-32.

El Malki K. G., Zidan Z. H., Gadallah A. I., Amin A. and Eissa, M. A. (1998). Relation between crop rotation regime and certain insect pests infestation at Qena Governorate. Proc. Seventh Conf. of Agric. Development Research, Cairo, Egypt, 15-17 Dec. Annals of Agric. Science, Cairo, Special Issue, Vol. 1:223-235.

Khattab M. M. (1988). A Screening of Occluded Viruses of Certain Lepidopterous Cotton Pests in Egypt with a Special Reference to Cutworms. M. Sc. Thesis, Fac. Agric., Cairo Univ., $125 \mathrm{pp}$.

Khattab M. M. (2003). Enhancement and Protection of Baculoviruses Infectivity Against the Adverse Effect of Sunlight. Ph.D. Thesis, Fac. Agric., Cairo Univ., 178 pp. 
Molyneux A.S and Bedding R.A(1984). Influence of soil texture and moisture on the infectivity of Heterorhabditis spp. DI and Steinernema glaseri for larvae of the blowfly Lucilia. Nematologica, 30: 328.

Wilson M. J., Glen D. M., George S. K., Pearce J. D. and Wiltshire C. W. (1994). Biological control of slugs in winter wheat using the rhabditid nematode
Phasmarhabditis hermaphrodita. Annals of Applied Biology, 125: 377 - 390.

Wilson M. J., Hughes L. A., Hamacher G. M., Barahona L. D. and Glen D. M. (1996). Effect of soil incorporation on the efficacy of the rhabditid nematode Phasmarhabditis hermaphrodita as a biological control agent for slugs. Annals of Applied Biology , 128 : $117-126$.

$$
\begin{aligned}
& \text { تأثير نيماتودا القواقع Phasmarhabditis tawfiki Azzam علي بعض أنواع القواقع } \\
& \text { والحثرات في انواع مختلفه من التربه تحت ظروف الصوبة الزجاجية } \\
& \text { كريمة محمود عزام - ماجدة محمد خطاب - الهام علّ الدين خليفة } \\
& \text { معهد بحوث وقاية النبات-مركز البحوث الزر اعية ـ الدقى ـ الجيزة- مصر. }
\end{aligned}
$$

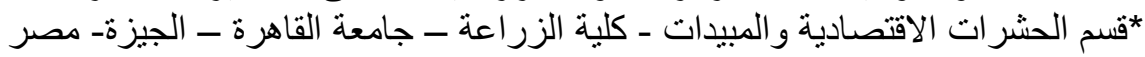

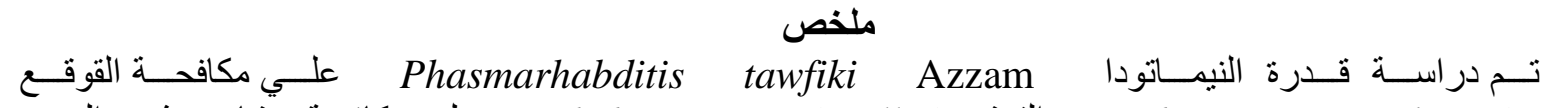

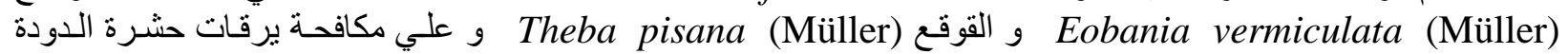

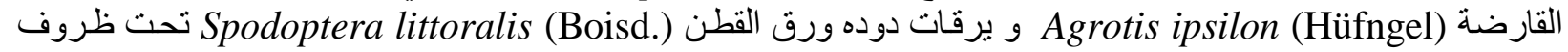

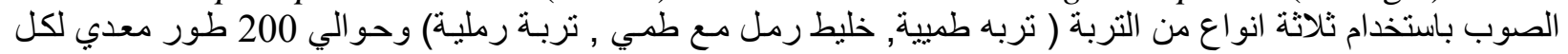

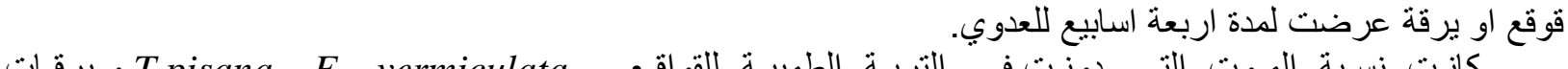
كانـت نسـبة المسوت التـي دونـت في في التربـة الطمييـة للقواقع الحشر ات

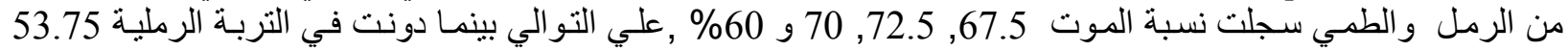
63.75, كما تم تسجيل أكبر عدد من الطور المعدي للنيمـاتودا (

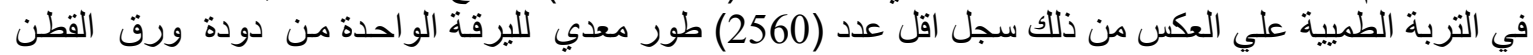

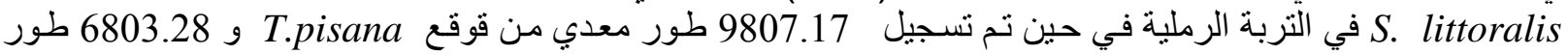

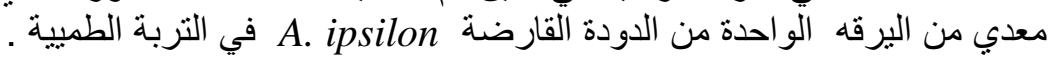

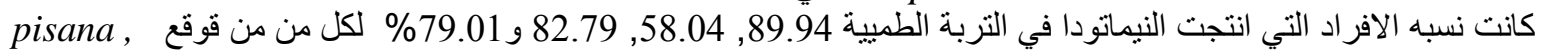

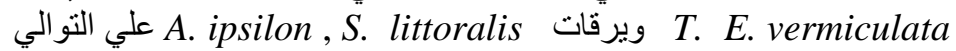

